\title{
PHOTOSYNTHESIS OF Physalis peruviana UNDER DIFFERENT DENSITIES OF PHOTONS AND SALINE STRESS
}

\author{
Francisco Romário Andrade FIGUEIREDO ${ }^{1}$ (iD), João Everthon da Silva RIBEIRO² (D), \\ Jackson Silva NÓBREGA ${ }^{3}$ (D), Wilma Freitas CELEDÔNIO3 ${ }^{3}$, Reynaldo Teodoro de FÁTIMA ${ }^{4}$ (D), \\ Jean Telvio Andrade FERREIRA ${ }^{4}$ (D) , Thiago Jardelino DIAS ${ }^{5}$ (D), Manoel Bandeira de ALBUQUERQUE ${ }^{5}$ (D) \\ ${ }^{1}$ Postgraduate Program in Phytotechnics, Federal Rural University of the Semi-Arid, Mossoró, Rio Grande do Norte, Brazil. \\ 2 Private Practice, Mari, Paraíba, Brazil. \\ 3 Postgraduate Program in Agronomy, Federal University of Paraíba, Areia, Paraiba, Brazil. \\ 4 Postgraduate Program in Agricultural Engineering, Federal University of Campina Grande, Campina Grande, Paraiba, Brazil. \\ ${ }^{5}$ Department of Phytotechnics and Environmental Sciences, Federal University of Paraíba, Areia, Paraiba, Brazil.
}

Corresponding author:

Francisco Romário Andrade Figueiredo

Email: romarioagroecologia@yahoo.com.br

How to cite: FIGUEIREDO, F.R.A., et al. Photosynthesis of Physalis peruviana under different densities of photons and saline stress. Bioscience Journal. 2021, 37, e37082. https://doi.org/10.14393/BJ-v37n0a2021-53948

\begin{abstract}
Physalis peruviana L. is a solanacea that has been gaining prominence due to its fruits presenting good acceptance in the national and international market. However, several abiotic factors, such as salinity, can cause physiological disturbances in plants, and these changes may be of greater or lesser intent according to species. Therefore, the objective of the present work was to evaluate the physiological behavior of $P$. peruviana submitted to different fluxes of photosynthetically active photons (PPFD) and saline stress. The experimental design was a randomized block design with three saline levels (ECW) $\left(0.5,2.75\right.$ and $5.00 \mathrm{dS} \mathrm{m}^{-}$ $\left.{ }_{1}^{1}\right)$ with four replications. Gas exchange measurements were performed with a portable infrared gas analyzer. Liquid $\mathrm{CO}_{2}$ assimilation, stomatal conductance, internal $\mathrm{CO}_{2}$ concentration, water use efficiency and instantaneous carboxylation efficiency were measured. Data were subjected to analysis of variance by $F$ test and in cases of significance applied to regression analysis. The increase in PPFD provided reductions in stomatal conductance up to the density of approximately $400 \mu \mathrm{mol} \mathrm{m} \mathrm{s}^{-2}$, being more pronounced in ECW of 2.75 and $5.0 \mathrm{dS} \mathrm{m}^{-1}$. The maximum $\mathrm{CO}_{2}$ assimilation rates in the three salinities are different according to the PPFD. The salinity of irrigation water reduced the quantum efficiency of photosynthesis in $P$. peruviana plants.
\end{abstract}

Keywords: Gas Exchange. Light Compensation. Salinity.

\section{Introduction}

Physalis peruviana $\mathrm{L}$. is an exotic plant belonging to the family Solanaceae, perennial herbaceous, semi-shrub and that attracts great interest because of its nutritional and functional properties (Bravo and Osorio 2016). In Brazil, the North and Northeast regions stand out as the largest producers (Rezende et al. 2018); however, their growth and development can be affected by several biotic and abiotic factors.

Among the abiotic factors, luminosity is one of the majors, where inadequate deviations and oscillations can damage plants, limiting their physiological processes, among them, photosynthesis (Santos et al. 2014). Plants under poor lighting conditions are reduced photosynthetic process, reflected in a lower production of carbohydrates (glucose, sucrose and starch), which would be evidenced in their relative growth (Melo Júnior 2015). 
As a response to these adversities, plants tend to adapt their photosynthetic apparatus, in order to use light more efficiently, but the mechanism varies among species (Bonamigo et al. 2016). However, the salinity of soil or irrigation water can cause reductions in the photosynthetic process, either by stomatal factors or due to physiological damages. In addition to limiting plant growth and production, saline stress impairs physiological processes and nutrient uptake, causing nutritional imbalance or ionic toxicity (Bekhradi et al. 2015).

The deleterious effects of salinity under the physiological aspects of the crops are reported by several authors, such as Bosco et al. (2015) in eggplant plants (Solanum melongena L.), Bezerra et al. (2019) in yellow passion fruit (Passiflora edulis Sims.) and Silva et al. (2019) in basil (Ocimum basilicum L.). Therefore, the knowledge about the behavior of plants in response to the variation of environmental conditions allows the management to be adequate, which offers, with maximum efficiency, to occur more favorable conditions for the physiological processes (Machado et al. 2005).

Thus, the objective of the present work was to evaluate the physiological behavior of Physalis peruviana submitted to different densities of photons and saline stress.

\section{Material and Methods}

The research was carried out in a greenhouse belonging to the Department of Plant Science and Environmental Sciences of the Center of Agricultural Sciences, Federal University of Paraíba, Areia - PB, Brazil ( $6^{\circ} 58$ ' $00^{\prime}$ 'S and $35^{\circ} 41^{\prime} 00^{\prime \prime} \mathrm{W}$ ). The climate of the region, according to Köppen is type As' which means dry and hot summer and rains in the winter (Alvares et al. 2013).

Seeds of mother plants produced in a greenhouse belonging to the Agro - Food Science and Technology Center, Federal University of Campina Grande, Pombal - PB, Brazil, were used. They were sown in polyethylene bags with a capacity of $1.2 \mathrm{dm}^{-3}$, filled with substrate composed of soil type Regolithic dystrophic Neosol (Embrapa 2018), cattle manure and sand washed in the proportion 3: 1: 1.

A randomized complete block design with three levels of electrical conductivity of irrigation water (ECW) $\left(0.5,2.75\right.$ and $\left.5.00 \mathrm{dS} \mathrm{m}^{-1}\right)$ with four replications was used. The waters of different electrical conductivities were prepared by adding sodium chloride $(\mathrm{NaCl})$ to the water of the UFPB supply system (ECW $=0,5 \mathrm{dS} \mathrm{m}^{-1}$ ) in the proportions required, with the values measured with a Instrutherm microprocessed model portable conductivity meter (model CD-860). Irrigation was carried out daily, with the application of saline water at 15 days after sowing (DAS). The applied volume was established by the drainage lisimetry method, based on the difference between the amount applied and drained.

At 75 DAS, the gas exchange was measured, in relation to the variation of the photosynthetic photon flux density (PPFD), with values ranging from 0 to $2000 \mu \mathrm{mol} \mathrm{m} \mathrm{m}^{-2} \mathrm{~s}^{-1}$, between 9 and $10 \mathrm{AM}$, in completely expanded leaves. These measurements were performed with a portable infrared gas analyzer - IRGA (model LI-6400XT, LI-COR ${ }^{\circ}$, Nebraska, USA) equipped with a light source and an automatic $\mathrm{CO}_{2}$ injection system (400 ppm) and with $300 \mu \mathrm{mol} \mathrm{s}^{-1}$ airflow, both programmable. This system also allows the PPFD to be controlled and programmed. The results obtained were: net assimilation of $\mathrm{CO}_{2}(A)\left(\mu \mathrm{mol} \mathrm{CO}_{2} \mathrm{~m}^{-2} \mathrm{~s}^{-1}\right)$, stomatal conductance (gs) (mol m $\mathrm{m}^{-2} \mathrm{~s}^{-1}$ ), internal $\mathrm{CO}_{2}$ concentration (iC) $\left(\mu \mathrm{mol} \mathrm{CO}_{2} \mathrm{~m}^{-2} \mathrm{~s}^{-1}\right)$, water use efficiency (WUE: $A / E$ ) and instantaneous carboxylation efficiency (iCE: $A$ /iC).

The response curves of the gas exchanges to PPFD were obtained with a decrease of 2.000 up to 200 $\mu \mathrm{mol} \mathrm{m} \mathrm{m}^{-2} \mathrm{~s}^{-1}$, at intervals of approximately $200 \mu \mathrm{mol} \mathrm{m} \mathrm{s}^{-2}$. Below $200 \mu \mathrm{mol} \mathrm{m} \mathrm{m}^{-2} \mathrm{~s}^{-1}$ to 0 , the PPFD was varied at smaller intervals $\left(25 \mu \mathrm{mol} \mathrm{m} \mathrm{m}^{-2} \mathrm{~s}^{-1}\right)$ in order to obtain several points and calculate the apparent quantum efficiency $\left(\Phi\left[\mu \mathrm{mol} \mathrm{CO}_{2} / \mu \mathrm{mol}\right.\right.$ photons]). This efficiency was estimated by fitting a linear equation in the range where the variation of $\mathrm{A}$ as a function of PPFD was linear, ie, $A=a+\Phi \times \mathrm{Q}$, where "a" and $\Phi$ are fit coefficients and $Q$ represents the PPFD. At the intersection of the line on the $X$-axis, we have the value of the light compensation point $\Gamma\left(\mu \mathrm{mol} \mathrm{m} \mathrm{m}^{-2} \mathrm{~s}^{-1}\right)$. The response curve of $A$ as a function of PPFD was adjusted to the rectangular hyperbola function, $\mathrm{A}=A_{\max } \mathrm{Q} / a+\mathrm{Q}$, where $A_{\max }$ is the maximum rate of photosynthesis and " $a$ " is a coefficient of adjustment of equation (Machado et al. 2005).

To verify the correlations between ecophysiological variables ( $A, \mathrm{gs}, \mathrm{Ci}$, WUE and $\mathrm{iCE}$ ), a multivariate analysis was performed using Principal Component Analysis (PCA). The data were submitted to analysis of variance by the $F$ test and in the cases of significance, the regression analysis was applied. Analyzes were performed using the SAS ${ }^{\oplus}$ statistical software (Cody 2015). 


\section{Results and Discussion}

The net assimilation of $\mathrm{CO}_{2}(A)$ increased with increasing PPFD, where the maximum rates of $A$ were 4.39; 2.36 and $4.14 \mu \mathrm{mol} \mathrm{m} \mathrm{m}^{-2}$ at the salinities of $0.5 ; 2.75$ and $5.0 \mathrm{dS} \mathrm{m}^{-1}$, respectively (Figure 1). These values indicate that there were differences in the electron transport capacity and $\mathrm{CO}_{2}$ assimilation with the increase of saline levels. It is noted that the increase in saline levels led to decreases in $A$, a fact also observed by Tatagiba et al. (2014) in tomato (Solanum lycopersicum L.), such reductions can be attributed to both stomatal factors as well as damage occurring in the photosynthetic apparatus of the crop.
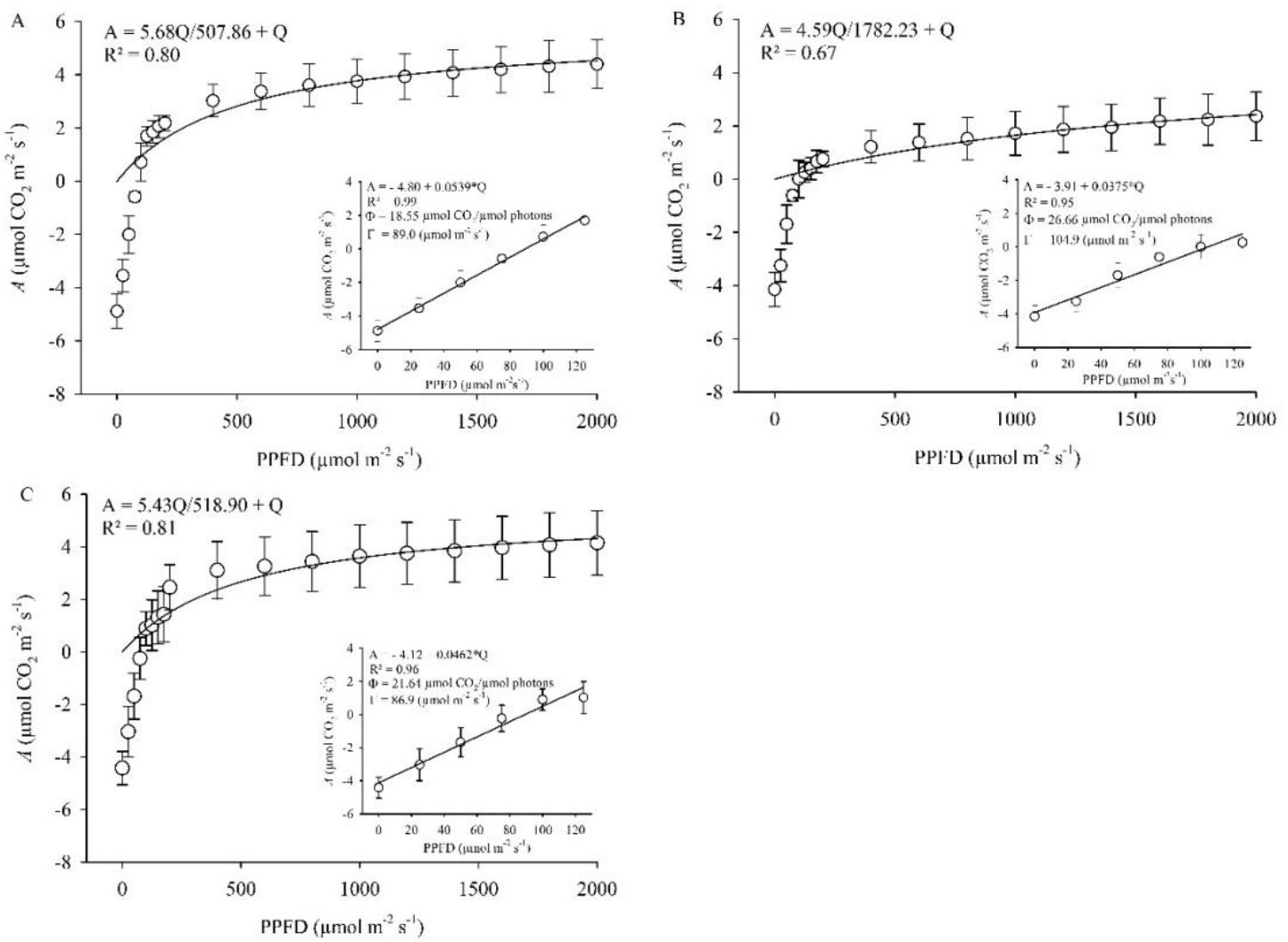

Figure 1. Rate of net assimilation of $\mathrm{CO} 2$ according to the photosynthetic photon flux density (PPFD) in Physalis peruviana submitted to the salinities. A - salinity of $0.5 \mathrm{dS} \mathrm{m}^{-1} ; \mathrm{B}$ - salinity of $2.75 \mathrm{dS} \mathrm{m}^{-1} ; \mathrm{C}-$ salinity of $5.0 \mathrm{dS} \mathrm{m}^{-1}$. Detail inserted inside the main figure shows the apparent quantum efficiency $(\Phi)$ and the light compensation point (Г). Bars represent standard deviation of four replicates.

However, it can be observed that in the higher saline level $\left(5.0 \mathrm{dS} \mathrm{m}^{-1}\right)$ the values are similar to the control treatment (Figures $1 \mathrm{~A}$ and $1 \mathrm{C}$ ). This behavior may be associated with secondary routes for the production of protective organic compounds, such as proline, where they are compartmentalized in the vacuole, thus, in an attempt to minimize the effects of stress, there may have been an increase in $\mathrm{CO}_{2}$ assimilation (Brito et al. 2016).

The light saturation points were not evident, as small additions were observed in $A$ as a function of PPFD increase (Figures $1 \mathrm{~A}, 1 \mathrm{~B}$ and $1 \mathrm{C}$ ). The quantum efficiency of photosynthesis ( $\Phi$, coefficient of the linear region of the light response curve) was 0.0110 .003 and $0.010 \mu \mathrm{mol} \mathrm{CO}_{2}\left(\mu \mathrm{mol}\right.$ photons ${ }^{-1}$ ), respectively, in the ECW of $0.5 ; 2.75$ and $5.0 \mathrm{dS} \mathrm{m}^{-1}$. By the inverse of this quotient, it can be stated that, in order to fix one mole of $\mathrm{CO}_{2}, 19,27$ and 22 mol photons, respectively, are required for the aforementioned ECW.

These values indicate that irrigation water salinity negatively influenced the efficiency of ATP and NADPH use in the Calvin cycle (Machado et al. 2005). Generally, the values for $\Phi$ are determined under low irradiance, however, this parameter can be influenced by several factors, such as $\mathrm{CO}_{2}$ concentration, temperature, humidity, and oxygen concentration in the leaf environment, due to the photorespiration process, especially in species of $C_{3}$ metabolism (Marenco et al. 2014).

The light compensation points were $89.0 ; 104.9$ and $86.9 \mu \mathrm{mol} \mathrm{m} \mathrm{m}^{-2} \mathrm{~s}^{-1}$, at the salinities of $0.5 ; 2.75$ and $5.0 \mathrm{dS} \mathrm{m}^{-1}$, respectively (Figures $1 \mathrm{~A}, 1 \mathrm{~B}$ and $1 \mathrm{C}$ ). The PPFD in which the plants reach their point of light compensation may vary between species and under the conditions in which they are submitted, but 
generally vary between 10 and $20 \mu \mathrm{mol} \mathrm{m} \mathrm{m}^{-2} \mathrm{~s}^{-1}$ (Taiz et al. 2017), values below those found in the present study. This behavior is characteristic of less tolerant species, which are not able to produce assimilates under low light intensity, which makes them have a high compensating point (Ortega et al. 2006).

For the stomatal conductance (gs), there was a reduction up to approximately the PPFD of $400 \mu \mathrm{mol}$ $\mathrm{m}^{-2} \mathrm{~s}^{-1}$, where the greatest decreases were observed in the treatments in which the plants were submitted to saline stress, above that value gs remained constant (Figure $2 A$ ). These results differ from those found by Lawson and Blatt (2014) and Hernández and Kubota (2016), where they showed that the increase in PPFD gives increases in gs. However, biotic and abiotic stresses may prevent plants from expressing their maximum genetic potential, as well as causing changes in the regular patterns of their metabolism (Krishania et al. 2013; Filgueiras et al. 2020).
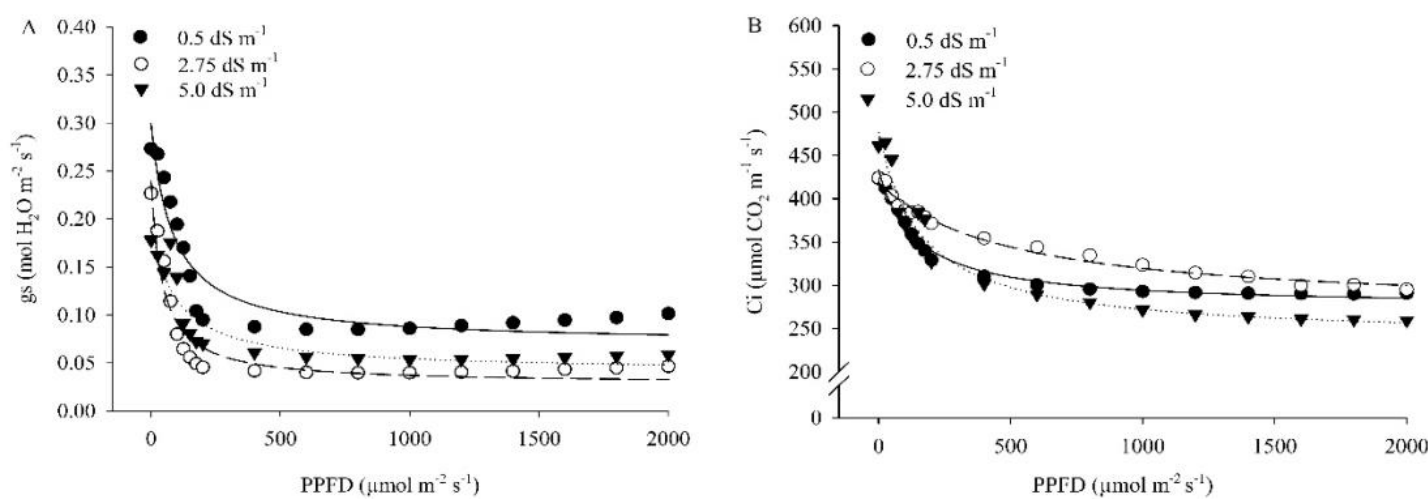

Figure 2. A - stomatal conductance; $\mathrm{B}-\mathrm{CO}_{2}$ internal concentration according to the photosynthetic photon flux density (PPFD) in Physalis peruviana submitted to the salinities of $0.5(\bullet), 2.75$ (o) e $5.0 \mathrm{dS} \mathrm{m}^{-1}$

$(\nabla)$. Bars represent standard deviation of four replicates.

The internal concentration of $\mathrm{CO}_{2}(\mathrm{Ci})$ was reduced with the increase of PPFD, with the highest concentrations at salinities of $2.75 ; 0.5$ and $5.0 \mathrm{dS} \mathrm{m}^{-1}$, respectively (Figure 2B). This behavior can be attributed both to the increase in the photosynthetic rate, as well as the stomatal limitation, possibly due to the higher rate of consumption in relation to the $\mathrm{CO}_{2}$ influx. These results also show that $\mathrm{CO}_{2}$ was being used for the synthesis of sugars by photosynthesis (Freire et al. 2014).

For water use efficiency (WUE), there were increases with PPFD increase for the three saline levels tested (Figure 3A). Possibly, this increment is related to the reduction of gs, which induces a lower transpiration and, consequently, less loss of water. Corroborating this statement, Tatagiba et al. (2015) argue that stomatic limitations provide reductions in $\mathrm{CO}_{2}$ entry into the carboxylation site and conserve water, which reduces the risk of dehydration.
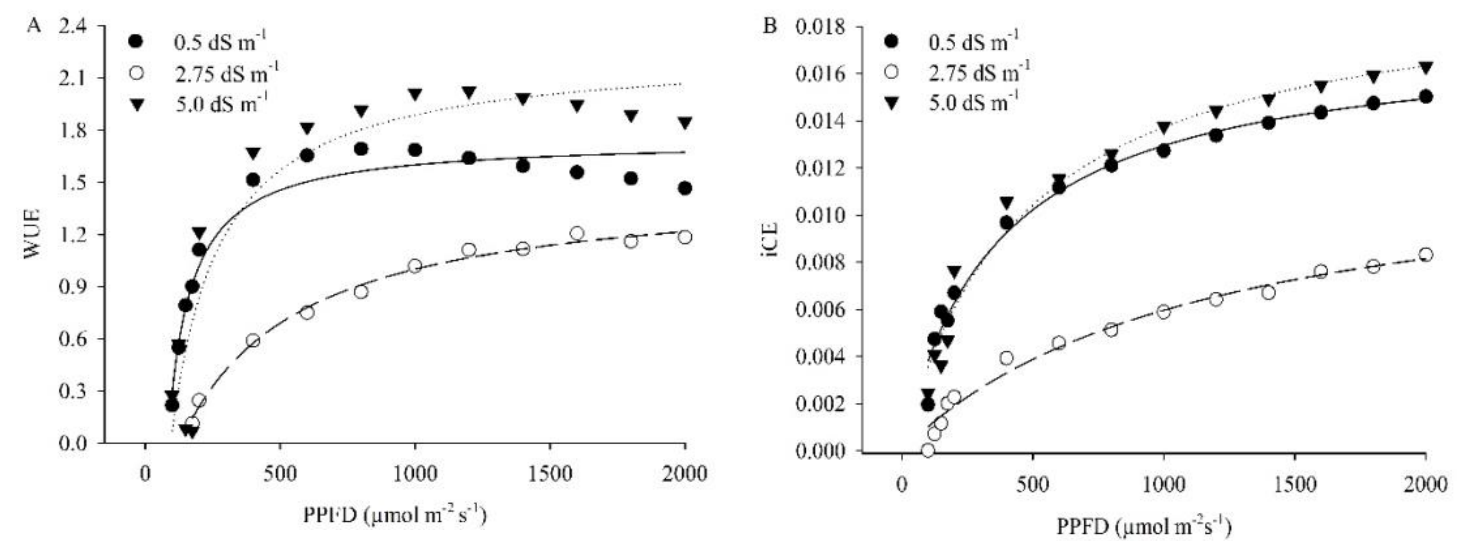

Figure 3. A - efficiency of water use; B - instantaneous carboxylation efficiency according to the photosynthetic photon flux density (PPFD) in Physalis peruviana submitted to salinities of $0.5(\bullet) 2.75$ (0) and $5.0 \mathrm{dS} \mathrm{m}-1(\boldsymbol{\nabla})$. Bars represent standard deviation of four replicates. 
The instantaneous carboxylation efficiency (iCE) showed a similar behavior to that of $A$ and inversely to that of iC (Figure 3B), showing a close relationship with these variables, since it is obtained by $A / i C$ ratio. Accordingly, reductions in the gas could have reduced the $\mathrm{CO}_{2}$ entering the mesophyll, but consumption in the chloroplast may have been induced (Suassuna et al. 2014). Thus, it is possible that such results are due to the greater assimilation of $\mathrm{CO}_{2}$ in relation to $\mathrm{CO}_{2}$ found in the substamatic chamber (Lima et al. 2017).

According to the principal component analysis (PCA), the concentration of $95.44 \%$ of the total variability of the first two axes (components) was observed, with $80.45 \%$ (PC1) and $14.99 \%$ (PC2), respectively (Figure 4). The net assimilation of $\mathrm{CO}_{2}(A)$ is strongly correlated with water use efficiency (WUE) and instant carboxylation efficiency (iCE) (Figure 4).

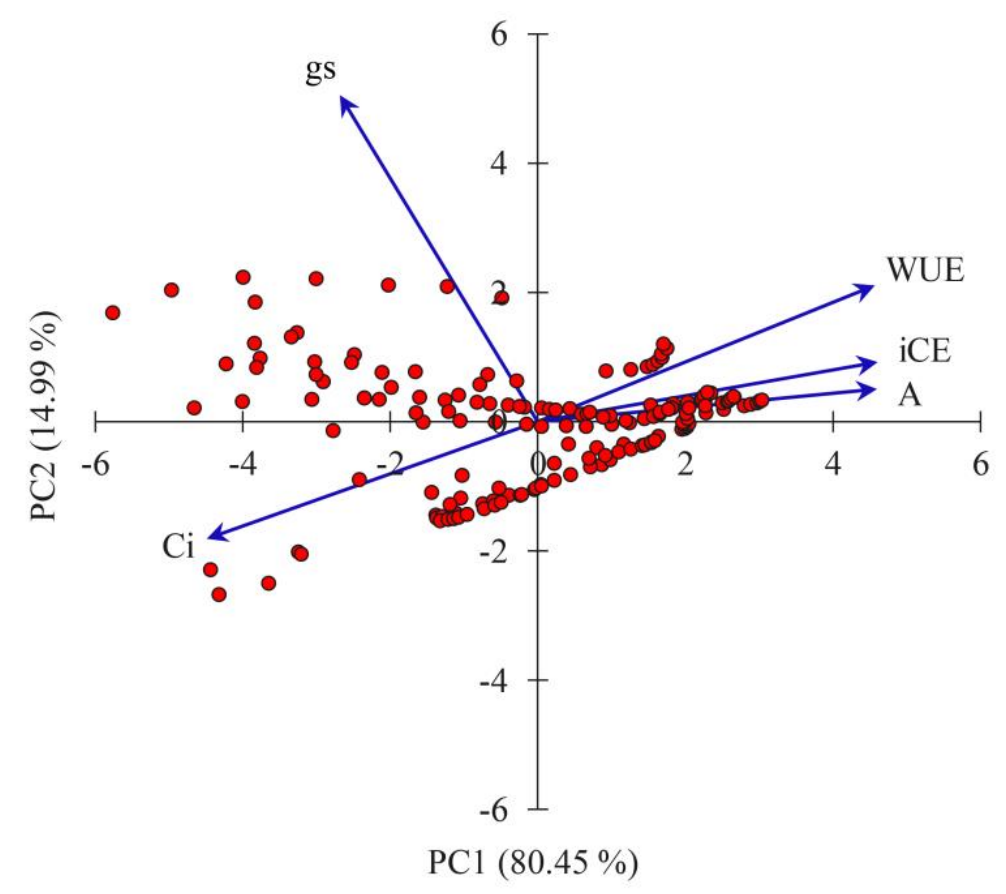

Figure 4. Principal Component Analysis (PCA; $P C 1$ and $P C 2)$ between net assimilation of $\mathrm{CO}_{2}(A)$, stomatal conductance (gs), internal $\mathrm{CO}_{2}$ concentration (Ci), water use efficiency (WUE) and instantaneous carboxylation efficiency (iCE).

On the main axis (PC1), the eigenvectors of net $\mathrm{CO}_{2}$ assimilation, water use efficiency and instant carboxylation efficiency are arranged in the extreme right portion, with positive values, while the eigenvector of the internal $\mathrm{CO}_{2}$ concentration is in the left portion, with negative values, thus showing the distinction between the behavior of these variables, with a reduction in the internal concentration of $\mathrm{CO}_{2}$ with the increase in the net assimilation of $\mathrm{CO}_{2}$.

\section{Conclusions}

The maximum $\mathrm{CO}_{2}$ assimilation rates in the three salinities are different according to the PPFD.

Increase in PPFD provided reductions in stomatal conductance up to the density of approximately $400 \mu \mathrm{mol} \mathrm{m} \mathrm{m}^{-2}$, being more pronounced in ECW of 2.75 and $5.0 \mathrm{dS} \mathrm{m}^{-1}$.

The salinity of irrigation water reduced the quantum efficiency of photosynthesis in Physalis peruviana plants.

Authors' Contributions: FIGUEIREDO, F.R.A.: conception and design, acquisition of data, analysis and interpretation of data, drafting the article; RIBEIRO, J.E.S.: acquisition of data, analysis and interpretation of data, drafting the article; FÁTIMA, R.T.: conception and design, acquisition of data, analysis and interpretation of data, drafting the article; NÓBREGA, J.S.: conception and design, acquisition of data, analysis and interpretation of data, drafting the article; FERREIRA, J.T.A.: acquisition of data, analysis and interpretation of data, drafting the article; CELEDÔNIO, W.F.: analysis and interpretation of data, drafting the article; DIAS, T.J.: analysis and interpretation of data, drafting the article; ALBUQUERQUE, M.B.: analysis and interpretation of data, drafting the article. All authors have read and approved the final version of the manuscript. 
Conflicts of Interest: The authors declare no conflicts of interest.

Ethics Approval: Not applicable.

Acknowledgments: The authors would like to thank the funding for the realization of this study provided by the Brazilian agencies CAPES (Coordenação de Aperfeiçoamento de Pessoal de Nível Superior - Brasil), Finance Code 001, and CNPq (Conselho Nacional de Desenvolvimento Científico e Tecnológico - Brasil).

\section{References}

ALVARES, C.A., et al. Köppen's climate classification map for Brazil. Meteorologische Zeitschrift. 2016, 22(6), 711-728. https://orcid.org/0000$\underline{0003-1871-0046}$

BEKHRADI, F., et al. Effects of salt stress on physiological and postharvest quality characteristics of different Iranian genotypes of basil. Horticulture Environment and Biotechnology. 2015. 56(6), 777-785. https://doi.org/10.1007/s13580-015-1095-9

BEZERRA, M.A.F., et al. Saline water, pit caoting and calcium fertilization on clorophyll, fluorescence, gas exchange and production in passion fruit. Journal of Agricultural Science. 2019, 11(2), 319-329. https://doi.org/10.5539/jas.v11n2p319

BONAMIGO, T., SCALON, S.P.Q. and PEREIRA, Z.V. Substratos e níveis de luminosidade no crescimento inicial de mudas de Tocoyena formosa (Cham. \& Schltdl.) K. Schum. (Rubiaceae). Ciência Florestal. 2016, 26(2), 501-511. http://dx.doi.org/10.5902/1980509822750

BOSCO, M.R.O., et al. Efeito do NaCl sobre o crescimento, fotossíntese e relações hídricas de plantas de berinjela. Revista Ceres. 2009, 56(3), 296-302.

BRAVO, K., and OSORIO, E. Characterization of polyphenol oxidade from Cape gooseberry (Physalis peruviana L.) fruit. Food Chemistry. 2016, 197, 185-190. https://doi.org/10.1016/j.foodchem.2015.10.126

BRITO, M.E.B., et al. Gas exchange and fluorescence of citrus rootstocks varieties under saline stress. Revista Brasileira de Fruticultura. 2016, 38(2), 1-8. http://dx.doi.org/10.1590/0100-29452016951

CODY, R. An Introduction to SAS University Edition. Cary: SAS Institute, 2015.

EMBRAPA. Sistema brasileiro de classificação de solos. 5 ed. Brasília, DF: Embrapa, 2018.

FILGUEIRAS, L., et al. Gluconacetobacter diazotrophicus mitigates drought stress in Oryza sativa L. Plant Soil. 2020, 451, 57-73. https://doi.org/10.1007/s11104-019-04163-1

FREIRE, J.L.O., et al. Rendimento quântico e trocas gasosas em maracujazeiro amarelo sob salinidade hídrica, biofertilização e cobertura morta. Revista Ciência Agronômica. 2014, 45(1), 82-91.

HERNÁNDEZ, R. and KUBOTA, C. Physiological responses of cucumber seedlings under different blue and red photon flux ratios using LEDs. Enviromental and Experimental Botany. 2016, 121, 66-74. https://doi.org/10.1016/j.envexpbot.2015.04.001

KRISHANIA, S., DWIVEDI, P. and AGARWAL, K. Strategies of adaptation and injury exhibited by plants under a variety of external conditions: a short review. Comunicata Scientiae. 2013, 4(2), 103-110. https://doi.org/10.14295/cs.v4i2.426

LAWSON, T. and BLATT, M.R. Stomatal size, speed, and responsiveness impacto n photosynthesis and water use efficiency. Plant Physiology. 2014, 164, 1556-1570. https://doi.org/10.1104/pp.114.237107

LIMA, G.S., et al. Trocas gasosas, pigmentos cloroplastídicos e dano celular na mamoeira sob diferentes composições catiônica da água. Irriga. 2017, 22(4), 757-774. http://dx.doi.org/10.15809/irriga.2017v22n4p757-774

MACHADO, E.C., et al. Respostas da fotossíntese de três espécies de citros a fatores ambientais. Revista Agropecuária Brasileira. 2005, 40(12), 1161-1170.

MARENCO, R.A., et al. Fisiologia de espécies florestais da Amazônia: fotossíntese, respiração e relações hídricas. Revista Ceres. 2014, 61, 786789. http://dx.doi.org/10.1590/0034-737X201461000004

MELO JÚNIOR, R.P. Qual a influência da cor da luz na fotossíntese?. Caderno Brasileiro de Ensino de Física. 2015, 32(1), $287-290$.

https://doi.org/10.5007/2175-7941.2015v32n1p287

ORTEGA, A.R., et al. Avaliação do crescimento de mudas de Psidium cattleianum Sabine a diferentes níveis de sombreamento em viveiro. Cerne. 2006, 12(3), 300-308.

REZENDE, R.A.L.S., et al. Salt estress and exogenous silicon influence physiological and anatomical features of in vitro grown cape gooseberry. Ciência Rural. 2018, 48(1), 1-9. http://dx.doi.org/10.1590/0103-8478cr20170176

SANTOS, U.F., et al. Níveis de sombreamento na produção de mudas de pau-de-balsa (Ochroma pyramidale). Bioscience Journal. 2014, 30(1), 129-136.

SILVA, T.I., et al. Echophysiological aspects of Ocimum basilicum under saline stress and salicylic acid. Revista Brasileira de Ciências Agrárias. 2019, 14(2), 1-9. https://doi.org/10.5039/agraria.v14i2a5633 
SUASSUNA, J.F., et al. Trocas gasosas e componentes de crescimento em porta enxertos de citros submetidos à restrição hídrica. Irriga. 2014, 19(3), 464-477. https://doi.org/10.15809/irriga.2014v19n3p464

TAIZ, L., et al. Fisiologia e Desenvolvimento Vegetal. 6th ed. Porto Alegre: Artmed, 2017.

TATAGIBA, S.D., et al. Limitações fotossintéticas em folhas de plantas de tomateiro submetidas a crescentes concentrações salinas. Revista Engenharia na Agricultura. 2014, 22(2), 138-149. http://dx.doi.org/10.13083/1414-3984.v22n02a05

TATAGIBA, S.D., PEZZOPANE, J.E.M. and REIS, E.F. Fotossíntese em Eucalyptus sob diferentes condições edafoclimáticas. Revista Engenharia na Agricultura. 2015, 23(4), 336-345. https://doi.org/10.13083/reveng.v23i4.573

Received: 21 April 2020 | Accepted: 14 August 2020 | Published: 29 December 2021

This is an Open Access article distributed under the terms of the Creative Commons Attribution License, which permits unrestricted use, distribution, and reproduction in any medium, provided the original work is properly cited. 